\title{
TELAAH KRITIS KONSEP IDE BESAR (FRITJOF CAPRA), ANYTHING GOES (PAUL FEYERABEND), DAN KRISIS SAINS MODERN (RICHARD TARNAS), DALAM UPAYA REKONSTRUKSI PEMIKIRAN PENDIDIKAN ISLAM
}

\author{
Muhamad Priyatna ${ }^{1}$ \\ ${ }^{1}$ Dosen Tetap Prodi Pendidikan Agama Islam STAI Al Hidayah Bogor \\ Email: priyatna@staialhidayahbogor.ac.id \\ Blog: http://priyatna.staialhidayahbogor.ac.id/
}

Received: 02/01/2019, Accepted: 20/02/2019, Published: 25/02/2019

\begin{abstract}
Modern civilization which is considered as the answer and the ultimate result of human civilization turns out to cause many complex problems, so it requires answers to these problems. Experts feel that the answers to these problems can no longer be based on the paradigm of modernism, so they expressly state that the world in post or postmodernism requires another paradigm as an alternative solution or path. In other words in postindustrial society (read: postmodern), science experiences delegitimation because it is proven that it cannot defend itself against the negative effects it produces itself. The legitimacy of science which states that knowledge must be produced for the sake of knowledge, in modern times can no longer be fulfilled. Because knowledge turns out to be no longer produced for the sake of knowledge, but for profit, where the applicable criteria are no longer true-false, but the performative criteria are, to produce as much as possible with the smallest possible cost.
\end{abstract}

Keywords: study, critical, epistemology, capra, feyerabend, tarnas.

\begin{abstract}
ABSTRAK
Peradaban modern seringkali dipandang sebagai hasil puncak peradaban manusia, ternyata tidak sepenuhnya disepakati kebenarnnya, oleh karenanya terdapat banyak problem multidimensi, maka dibutuhkan solusi yang tepat terhadap segala problem-problem tersebut. Para ahli menyatakan bahwa jalan keluar dari permasalahan tersebut tidak lagi bisa ditangani oleh paradigma modernisme, sehingga mereka dengan tegas menyatakan, dunia pada pasca atau postmodernisme membutuhkan paradigma lain, terutama dalam upaya rekonstruksi pemikiran pendidikan. Pada masyarakat postmodern pasca industri, ilmu pada akhirnya mengalami delegitimasi, karena terbukti tidak dapat menghindar dari efek negatif yang dihasilkannya sendiri. Legitimasi yang menyatakan bahwa pengetahuan harus ditujukan demi pengetahuan, pada masa modern tidak dapat dipenuhi. Karena pengetahuan ternyata dihasilkan semata-mata untuk keuntungan semata, norma benarsalah tidak lagi berlaku sebagai standar, akan tetapi pragmatis demi menghasilkan sebesarbesarnya profit dengan pendanaan sedikit mungkin.
\end{abstract}

\section{A. PENDAHULUAN}

Kajian umum maupun kritis tentang problem filsafat ilmu, pada umumnya terjadi seputar masalah yang terkait dengan kebenaran (truth), kenyataan atau fakta, dan logika. Problem filsafat ilmu itu sendiri, bisa kita simpulkan mencakup pada beberapa problem, yaitu; pertama adalah pada problem ontologi ilmu pengetahuan itu sendiri; kebenaran ilmu pengetahuan 


\section{Telaah Kritis Konsep Ide Besar...}

yang berlandaskan pada norma ontologis yaitu 'apa yang terjadi' dan pada eksistensi wujud atau entitas). Kedua, pada problem epistemologi ilmu pengetahuan; yaitu pembahasan terkait asal, sifat natural, sejauh mana konsep dibatasi, sumber dari sebuah asumsi berasal, kaidah landasan berfikir yang digunakan, uji sebuah validitas dan reliabilitas dilaksanakan, hingga kepada masalah kebenaran itu sendiri, terkait bagaimana proses ilmu didapatkan serta bagaimana proses sebuah metoda dapat menggapai sebuah kebenaran. Selanjutnya problem yang ketiga adalah tentang aksiologi ilmu pengetahuan; dampak pada bidang etis, bidang estetis, deskripsi tentang peran dan manfaat ilmu dalam peradaban manusia. Kesemuanya tersebut di atas, dijadikan sebagai landasan penelitian ilmu dalam filsafat barat.

Problem penelitian ilmu tersebut telah menjadi diskursus hangat di kalangan para penggiatnya, kajiannya setara diskusi tentang landasan pengembangan ilmu pengetahuan itu sendiri yakni landasan ontologis, epistemologis, dan aksiologis. Dari sekian banyak tokoh, tersebutlah tiga tokoh filsafat kontemporer barat, yaitu Fritjop Capra, Paul Feyerabend, Richard Tarnas, dan melalui karya-karyanya, mereka ikut terlibat dalam wacana kritis epistemologi ilmu tersebut.
Oleh karena itu, ditegaskan pada awal tulisan ini, bahwa fokus dan pembatasan masalah kajian pada makalah ini adalah seputar kajian pemikiran ketiga tokoh filsafat kontemporer tersebut. Sedangkan metode yang dipilih dalam penyusunan tulisan ini adalah pendekatan kajian pustaka terhadap buah pemikiran yang bersumber dari karya tulis berupa buku, artikel maupun kutipan terhadap hasil telaah dan analisis buah pikiran oleh para peneliti terdahulu disertai analisis penulis.

\section{B. PEMBAHASAN}

1. Fritjop Capra

Fritjof Capra seorang tokoh yang berasal dari Austria, tepatnya dari kota Wina, lahir pada tanggal 01 Februari 1939. Capra menyelesaikan pendidikan studinya di universitas Wina. Di Universitas tersebut, Capra bertemu dan banyak mendapatkan pelajaran dari Werner Heisenberg, Heisenberg merupakan seorang ahli fisika yang menemukan teori The Uncertainty (ketidakpastian). Capra pada beberapa karyanya, didapati sering mengutip teori The Uncertainty Heisenberg. Capra lulus tahun 1966 dengan menyandang Ph.D dalam bidang fisika. ${ }^{1}$

Fritjof Capra merupakan seorang ahli fisikawan yang terkenal lewat karangan

1 http://www.fritjofcapra.net/, diakses 07 Oktober 2018. 
bukunya yang bejudul TheTurning Point (Titik Balik Peradaban) $^{2}$ dan The Tao of Physics (Fisika Tao). ${ }^{3}$ Capra juga seorang ahli yang dikenal sebagai fisikawan modern dan juga ahli dalam teori sistem, Capra juga dikenal sebagi ahli yang mengemukakan teori paradigma baru pada ilmu sosial, yang lebih dikenal dengan teori sistemik-holistik. ${ }^{4}$ Capra dalam karyakaryanya, dikenal juga ikut membahas berbagai permasalahan melalui pendekatan sains, serta membahas juga melalui kaca mata filsafat "timur", setidaknya menurut pengagumnya. Hal-hal tersebut di atas yang membuat Capra berbeda dengan ahli Fisikawan lainnya.

Saleh Daulay menyatakan, bahwa terlihat melalui gambaran biografi Capra adalah seorang ilmuwan murni yang karier awal akademiknya dimulai dengan banyak mengkaji secara mendalam ilmu fisika teoritis. Kemudian Capra menambah wawasan intelektualnya dengan belajar

2 Diterjemahkan oleh penerbit Bentang Budaya. (2002). Titik Balik Peradaban Sains, Masyarakat dan Kebangkitan Kebudayaan. jumlah halaman, 559+xxiii.

3 Diterjemahkan oleh penerbit Jalasutra. (2001). Tao of Physics: Menyingkap Paralelisme Fisika Modern dan Mistisisme Timur. jumlah halaman, 414+xvi.

4 Teori sistemik holistik merupakan paradigma baru yang digunakan untuk mengembangkan teori, ilmu, pengetahuan, praktek dan pola fikir untuk memecahkan masalah kerusakan sumber daya dan pencemaran lingkungan yang meluas. Paradigma ini hadir disebabkan karena paradigma lama (Cartesian) dipandang tidak memadai lagi untuk menjawab berbagai tantangan dan persoalan yangg dihadapi masyarakat modern. mistisisme Timur. Saleh melanjutkan, bahwa dalam karyanya, TheTao of Physics (1975), Capra mensosialisasikan pandangan barunya dalam teori fisika quantum serta teori relativitas menggunakan mistik Timur yang direinterpretasi secara holistik. Pandangan barunya tersebut kemudian secara sistematis diperdalam dengan membangun paradigma ekosistemik dalam The Turning Point (1982). Kemudian pandangan barunya tersebut disempurnakannya ke dalam sebuah sistem yang lebih kompleks dalam The Web of Life (1996). Capra juga menghasilkan buku lain diantaranya adalah Uncommon Wisdom (1988) dan The Hidden Connections (2002) dimana di dalamnya termuat pandangannya tentang kearifan Timur dalam sains modern. ${ }^{5}$

Lebih lengkap, Rizal Efendi merangkum resensi karya-karya utama dari Fritjof Capra, yang menurutnya, termasuk salah satu intelektual yang produktif, banyak karya yang telah ditulisnya, dan sebagian bukunya terdapat karya best seller yang merepresentasikan produk pemikirannya. $^{6}$ Menurut Rizal, karya Capra yang diminati tersebut adalah bukti

5 Saleh Daulay. (2012). Menelusuri JejakJejak Mistisisme dalam Sains Modern. Lihat http://www.salehdaulay.com/index.php/component/ k2/item/110-menelusuri-jejak-jejak-mistis medalam-sains-modern, diakses 02 Oktober 2018, pukul 13.53.

6 Rizal Efendi. (2009). Hubungan Antara Sains dan Agama dalam Pemikiran Fritjof Capra. Yogyakarta: UIN Yogya. hlm. 24. 


\section{Telaah Kritis Konsep Ide Besar...}

bahwa pemikirannya memang menarik dan layak dijadikan rujukan dalam melandasi konsep pemikiran dan pemahaman baru dalam usahanya meng-counter pandangan kaum modernitas yang pada konsepnya banyak mengurangi keterlibatan manusia pada aktifitasnya, akibatnya timbul problem pada sisi-sisi kemanusiaan. ${ }^{7}$

Diantara karya-karya tersebut adalah:

a. Buku The Tao of Phisyc: An Exploration of the Parallels Between Modern Physics and

\section{Easter Mysticism}

Menurut Rizal, ini buku Capra yang membuatnya dikenal, serta sangat laris diminati. Di dalamnya Capra menyatakan terdapat keserasian di antara mistisisme dengan temuan-temuan pada disiplin ilmu fisika terbaru, khususnya pada teori $s u b$ atomik dan relativistik. Dalam buku ini Capra berupaya untuk mengintegrasikan agama dengan sains. Dalam kesimpulan akhir dari bukunya, capra menyatakan antara mistisme dan sains memang sama dibutuhkan dalam kehidupan manusia, sehingga para fisikawan tidaklah harus bermeditasi dalam laku intelektualnya. ${ }^{8}$

b. Buku The Turning Point: Science, Society and The Rising Culture (1982)

Rizal menyatakan, paradigma dalam karya ini dapat mewakili sebuah

${ }^{7}$ Rizal Efendi. (2009). hlm. 24.

${ }^{8}$ Rizal Efendi. (2009). hlm. 24. pandangan Capra, yang terlihat berubah dari minat fisika-mistis mengarah kepada pandangan konsep biologis-ekologis. Capra menjelaskannya sebagai sebuah penemuan baru dalam bidang biologi paradigma baru yang disebutnya sebagai konsep ekologis-sistemik. Capra menyatakan pendapat tersebut sebagai sebuah sistem yang ada dalam organisme yang saling bergantung, dan dalam prosesnya proses organisme tersebut berproses secara swa-organisasi yang memiliki kekuatan untuk memperbaiki diri masing-masing ketika ada kerusakan, yang diidentifikasi sebagai sesuatu yang lain, yang tidak lain adalah Tuhan. ${ }^{9}$

c. Buku The Web of Life: A New Synthesis of Mind and Matter (1996)

Menurut Rizal, karya ini merupakan usaha Capra dalam melanjutkan buku sebelumnya, di dalamnya ia memberikan sintesis teori Chaos dan teori kompleksitas. Capra ingin membangun landasan teori kepada teori-teori sistem hidup sebagai dasar konseptual dari visi ekologis dari realitas. ${ }^{10}$

d. Buku The Hidden Connection: A Science for Sustainable Living (2003)

Capra dalam buku The Hidden Connection, menggambarkan fase ter-akhir

\footnotetext{
${ }^{9}$ Rizal Efendi. (2009). hlm. 24.

${ }^{10}$ Rizal Efendi. (2009). hlm. 25.
} 
filosofi pemikirannya pada beberapa pandangan fase awal pemikirannya. Menurut Rizal, terungkap sebuah pemikiran yang lebih membumi dalam karya ini, dengan ide-ide tentang problem industrialisasi, sistem ekonomi global, politik global, menurut Capra dapat diselesaikan dengan cara meninggalkan paradigma mekanistik menuju paradigma sistemik. $^{11}$

Rizal menyimpulkan, bahwa karya Capra yang telah disebutkan di atas, secara spesifik memiliki keterkaitan dalam proyeksi pandangan pemikiran Capra, terkhusus pada bidang sains serta spiritualitas sebagai pokok bahasan utamanya.

berdasarkan latar belakang akademik serta keterlibatan intelektual Fritjof Capra, maka dapat disimpulkan bahwa Capra banyak mencurahkan perhatiannya pada problem yang disebabkan oleh paradigma modernitas, atau oleh Capra disebut sebagai paradigma Mekanistis-Dualistis. Perhatian Capra secara khusus juga tertuju pada bagaimana menyusun konsep dasar sebuah paradigma atau pandangan yang peduli terhadap kesadaran lingkungan. ${ }^{12}$

2. Paul Karl Feyerabend

Paul Karl Feyerabend lahir di Wina Austria pada tahun 1924, Feyerabend

${ }^{11}$ Rizal Efendi. (2009). hlm. 25.

12 http://www.fritjofcapra.net/, Diakses 07 Oktober 2018. belajar tentang teater di sebuah teater di Waimar. Feyerabend sangat tertarik pada drama dan kesenian. Oleh karenanya tidak aneh jika tampak dalam karya-karyanya, terlihat dimana Feyerabend dalam menjabarkan pemikiran ilmiahnya menggunakan bentuk contoh pada bidang seni. $^{13}$

Dalam Listiyono, disebutkan, bahwa Feyerabend memperoleh gelar Doktor di Wina, Austria dalam bidang Fisika. Feyerabend pada awalnya meyakini bahwa ilmu pengetahuan adalah hal paling hebat serta ada norma hukum yang secara ilmiah dapat dipertanggungjawabkan dan berlaku universal dalam segala tindakan. Feyerabend mengikuti kelas filsafat Karl Popper di London pada tahun 50-an. Ketika itu, Feyerabend masih memegang teguh pemikiran rasionalitasnya, akan tetapi pada saat bersentuhan dengan pemikiran Lakatos, Feyerabend memiliki pemikiran yang berubah drastis. Feyerabend berpendapat bahwa terdapat pelanggaran pada prinsip-prinsip pokok mekanika kuantum, oleh karenanya Feyerabend berpendapat semua usaha pencarian hukum universal merupakan ilusi belaka. Pemikiran anarkisme ilmu pengetahuan Feyerabend mencapai puncak pemikiran yang disebut dengan istilah anarkis pada

\footnotetext{
${ }^{13}$ Listiyono Santoso. (2006). Seri Pemikiran Tokoh: Epistemologi Kiri. Jogjakarta: Ar-Ruzz Media. hlm. 149-150.
} 


\section{Telaah Kritis Konsep Ide Besar...}

saat berkenalan dengan seorang tokoh yang bernama Weizsacker. Pemikiran anarkisnya tersebut tertuang pada buku karangannya Against Method yang diterbitkan pada tahun 1970. Feyerabend, dapat dikelompokkan sebagai tokoh postmodernisme, jika dilihat dari pola pemikirannya dalam bidang filsafat ilmu ${ }^{14}$. Sehingga bentuk pemikirannya merupakan kritik terhadap paradigma modernisme dan pemikiran Descartes (Renaissance) serta Hegel, yang disebutnya dengan paradigma grand narratives yang dilegimitasikan, ${ }^{15}$ yaitu sebuah cara berpikir yang mengeneralisir di dalam menjelaskan multi aspek melalui grand theory (teori dasar) sebagaimana dinyatakan oleh tokoh postmodernisme. ${ }^{16}$

Menurut Verhak masyarakat pada masa Feyerabend, cenderung ilmu

14 Postmodernisme berarti, setelah modernisme. Modernisme dimulai pada tahun 1890 dan berlangsung sampai sekitar tahun 1945. Gerakan ini merupakan reaksi terhadap modernisme yang dipengaruhi oleh kekecewaan yang ditimbulkan oleh Perang Dunia II. Postmodernisme menentang penggunaan pemikiran logis yang didasarkan pada dasar yang tidak ilmiah dan proses berpikir irasional sebagai reaksi terhadap modernisme. Lihat https://id.wikipedia.org/wiki/Pascamodernisme

15 Grand Narratives adalah teori-teori atau konstruksi dunia yang mencakup segala hal dalam menetapkan kriteria kebenaran dan objektifitas dari ilmu pengetahuan. Sehingga konsekuensinya adalah narasi-narasi diluar narasi besar adalah narasi non-ilmiah. Lihat juga $w w w$. oxfordreference. com/view/ 10.1093/oi/ authority. 20110803095903493.

${ }^{16}$ Listiyono Santoso. (2006). Seri Pemikiran Tokoh. hlm. 149-150. pengetahuan diposisikan sama dengan agama bahkan di atasnya. ${ }^{17}$

Pemikiran Paul Feyerabend diklasifikasikan ke dalam paradigma radikal dan anarkis, disebabkan filsafat ilmu itu sendiri tidak berhasil secara valid menjelaskan paradigma umum tentang sains serta metode yang membedakan produk-produk yang dihasilkan pseudosains dibandingkan dengan sains murni. ${ }^{18}$

Seluruh pemikiran Feyerabend dikenal dengan istilah anarkisme epistemologis, yaitu suatu teori epistemologi yang memiliki pandangan, aturan metodologi khusus yang mengatur perkembangan sains atau pengetahuan itu sesungguhnya tidak ada. Karena seharusnya sains dikembangkan melalui regulasi universal tanpa harus merugikan dan membatasi sains itu sendiri. ${ }^{19}$

Konsekuensi dari pandangan tersebut adalah paradigma yang disebut anything goes (apapun boleh) terhadap metodologi. Feyerabend berpendapat demikian dikarenakan tidak adas metode ilmiah yang tetap, oleh karenanya ilmuwan harus memperlakukan sains sebagai gerakan

${ }^{17}$ C. Verhak. (1995). Filsafat Ilmu Pengetahuan. Jakarta: PT Gramedia Pustaka Utama. hlm. 167.

18 Yeremias Jena. (2010). Dimensi Dinamis Ilmu. Jakarta. Pseudosains adalah sebuah pengetahuan, metodologi, keyakinan, atau praktik yang diklaim sebagai ilmiah tapi tidak mengikuti metode ilmiah. Lihat https://id.wikipedia.org /wiki/Ilmu_semu.

19 https://id.wikipedia.org/wiki/Anarkisme_ epistemologis, diakses 20 Oktober 2015, pukul 14. 
pembebasan.Pengajuan gagasan ini membuat Feyerabend diberi gelar "musuh terburuk sains. ${ }^{20}$

Moch. Tasir menyatakan, bahwa teori tersebut merupakan suatu kritik feyerabend pada dua sisi, yaitu Anti Metode dan Anti Ilmu Pengetahuan. ${ }^{21}$

Pertama, Konsep Anti Metode, sebagaimana dijelaskan Moch. Tasir, bahwa dengan dalih kebebasan individu, Feyerabend ingin melawan metode baku dan universal dalam ilmu pengetahuan, yang telah disepakati para ilmuan serta telah mendasari semua fakta dan penelitian yang telah ada. Akan tetapi hal tersebut ditentang oleh Feyerabend, menurutnya hal tersebut adalah sebuah klaim, lebih jauh lagi itu adalah klaim yang tidak realistis dan jahat. ${ }^{22}$

Kedua, Konsep Anti Ilmu Pengetahuan, Tasir menjelaskan, bahwa dengan dalih kebebasan individu yang sama, Paul Feyerabend bersikap anti-ilmu pengetahuan dalam artian anti terhadap kekuasaan ilmu pengetahuan yang melampaui batas-batas kewenangannya. Dikarenakan pandangannya tersebut Paul Feyerabend secara langsung maupun tidak

20 https://id.wikipedia.org..., diakses 20 Oktober 2018, pukul 14.47.

${ }^{21}$ Moch Tasir. (2014). Paul Karl Feyerabend; Anything Goes Methode. Lihat http://philosopherscommunity. blogspot.co.id /2014/03/ paul-karlfeyerabend- anything- goes. Html,diakses 20 Oktober 2018, pukul 14.06.

22 Moch. Tasir. (2014). Paul Karl Feyerabend; Anything Goes Methode. langsung berhadapan dengan para ilmuwan, di dalam pandangan klaim yang sudah baku bahwa ilmu pengetahuan adalah lebih unggul dibandingkan dengan sihir, magic, mitos dan lain sebagainya sebagai wujud hasil entitas pemikiran lainnya. $^{23}$

Tasir dkk. melanjutkan, bahwa dalam pemikiran epistemologinya yang anarkis, ada beberapa hal yang diperjuangkan oleh Paul Karl Feyerabend, diantaranya adalah: $^{24}$

Apa Saja Boleh, dimana dalam pendapatnya, Paul Feyerabend mengklaim, sebagaimana digambarkan Tasir dkk., bahwa dikarenakan banyak sekali metode yang tidak sejalan dengan teori dan sejarah fisika, membuktikan bahwa tidak ada metodologi ilmu yang pernah dikemukakan selama ini mencapai sukses. ${ }^{25}$

Tidak bisa saling diukur dengan standar yang sama, Tasir dkk. menyatakan, bahwa suatu hal yang penting dari Paul Feyerabend adalah pendapatnya tentang ilmu-ilmu yang tidak bisa saling diukur dengan standar yang sama, karena

\footnotetext{
23 Moch. Tasir. (2014). Paul Karl Feyerabend; Anything Goes Methode.

24 Moch. Tasir. (2014). Paul Karl Feyerabend; Anything Goes Methode.

${ }^{25}$ Moch Tasir. (2014). Paul Karl Feyerabend; Anything Goes Methode. Lihat juga Donny Gahral Adian. (2002). Menyoal Objektivisme Ilmu Pengetahuan dari David Hume sampai Thomas Kuhn. Teraju: Jakarta. hlm.102-103.
} 


\section{Telaah Kritis Konsep Ide Besar...}

konsepsi tersebut dianggap sebagai ketergantungan observasi pada teori. ${ }^{26}$

\section{Ilmu tidak harus mengungguli} bidang-bidang lain, Tasir dkk. menyatakan bahwa Feyerabend mengemukakan masih banyak kaum metodologis yang sudah menganggap benar, tanpa argumentasi, bahwa ilmu (atau mungkin fisika) membentuk paradigma rasionalitas. ${ }^{27}$

Kebebasan Individu, Feyerabend menyatakan apa yang ia sebut sebagai "sikap kemanusiawian". Menurutnya manusia individual harus bebas dan memiliki kebebasan kurang lebih seperti di dalam pengertian John Stewart Mill yang membelanya dalam esai "On Liberty", Feyerabend menyetujui "Usaha meningkatkan kebebasan, untuk menuju ke kehidupan yang penuh dan produktif'. Ia mendukung John Stewart Mill dalam membela "Pembinaan individualitas yang secara pribadi berproduksi, atau dapat memproduksi manusia-manusia yang maju. $^{28}$

Menurut Feyerabend tidak ada yang baku baik secara logika maupun secara metodologi. Ini menyebabkan hilangnya otoritas pengetahuan yang dimiliki oleh

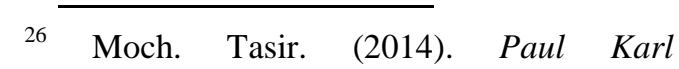
Feyerabend; Anything Goes Methode. Lihat juga C. Verhak. (1995). Filsafat Ilmu Pengetahuan. Jakarta: PT Gramedia Pustaka Utama. hlm. 167168.

${ }^{27}$ Moch. Tasir. (2014).
${ }^{28}$ Moch. Tasir. (2014). para ilmuan. Sesuatu ilmu tidak bisa dimonopoli oleh sebagian orang yang menetapkan kebenaran. Ini membawa kepada suatu pengetahuan yang lebih demokratis dan anarkistis. $^{29}$

Pendapatnya ini berasal dari pandangannya bahwa sebenarnya tidak ada suatu metodologi yang terus dipakai oleh komunitas ilmiah secara konsisten. Pada suatu kesempatan pasti ada pelanggaran dari komunitas ilmiah itu demi berkembangnya ilmu pengetahuan. Bahkan keberadaan satu metodologi tunggal, bisa jadi menyebabkan sains menjadi susah berkembang. Sains akan memperoleh keuntungan dengan anarkitisme teori dalam dosis yang tepat. Berlawanan dengan Lakatos, Feyerabend menyatakan bahwa sebenarnya tidak ada pemisah yang jelas antara sains dan pseudosains, sehingga sebuah hukum metodologi tunggal berbahaya. $^{30}$

Penulis menyimpulkan, bahwa ide Feyerabend dalam upaya memberikan sumbangan dalam ilmu pengetahuan, dengan semboyan "anything goes", ternyata metode tersebut juga menimbulkan pro dan kontra. Terdapat dampak yang mengancam tatanan kehidupan manusia. Contohnya adalah seperti peristiwa yang terjadi pada perang dunia ke-2, yaitu tragedi kemanusiaan akibat bom atom yang

${ }^{29}$ Moch. Tasir. (2014)

${ }^{30}$ Moch. Tasir. (2014). 
dijatuhkan Amerika Serikat di dua kota di Negara Jepang, yaitu di kota Hiroshima dan kota Nagasaki. Akibat negatif lainnya seperti penelitian dan produksi senjata nuklir, senjata biologi, dan senjata kimia yang dijadikan senjata pemusnah massal (mass destruction weapon), tentu saja sangat merugikan kehidupan manusia secara umum di masa mendatang. Oleh karenanya terdapat dampak negative dari paradigma anarkis Feyerabend, yaitu bahwa pada hakikatnya ilmu pengetahuan senantiasa berkembang terus, akan tetapi tidak ada yang dapat benar-benar mengontrol penggunaan ilmu pengetahuan itu sendiri.

\section{Richard Tarnas}

Richard Theodore Tarnas, lahir 21 Februari 1950, di Jenewa, Swiss, adalah seorang sejarawan budaya dikenal bukunya The Passion of the Western Mind: Understanding the Ideas That Have Shaped Our World View (1991), Cosmos and Psyche: Intimations of a New World View (2006). Tarnas adalah profesor filsafat dan psikologi di California Institute of Integral Studies, dan direktur pendiri program pascasarjana pada Philosophy, Cosmology, and Consciousness. ${ }^{31}$

\section{The Crisis of Modern Science}

Richard Tarnas dikenal dengan teorinya, yang menyatakan bahwa sains

$31 \quad$ https://en.wikipedia.org/wiki/Richard Tarnas, diakses 20 Oktober 2018, pukul 08.30. modern yang mainstreamnya berkiblat ke barat, memiliki banyak celah yang masih lemah, serta tidak terbukti mampu berhasil memberikan solusi pemecahan terhadap problem-problem kehidupan yang mendasar sekalipun, oleh karenanya ia menggagas satu ide "mainstream" baru yang lebih baik dan benar.

Cecep Zafar Sofyan menyatakan, bahwa Tahun 1991, Tarnas menulis buku dengan judul "The Passion of the Western Mind“", yang dalam buku tersebut ada satu bab yang menarik perhatian publik, dengan judul "The Crisis of Modern Science", ${ }^{32}$

Cecep meresume dan merinci kesalahan-kesalahan ilmu Barat sekuler dalam buku tarnas tersebut, di antaranya, Pertama, Ide dasar ilmu pengetahuan di Barat adalah "space", "matter", "causality" dan "observation", akan tetapi ternyata semuanya tidak terbukti benar. Pandangan yang sekarang berlaku adalah space sesungguhnya adalah terbatas (finite), akan tapi lepas; serta juga pada ternyata bentuknya lengkung/tidak linier, sehingga garis edar/orbit benda-benda angkasa berbentuk elips, bukan karena tertarik oleh gaya gravitasi ke matahari, tapi memang bentuknya lengkung. Kemudian kini berlaku empat dimensi

32 Cecep Zafar Sofyan. (2015). Merenungi Kenyataan dengan Nalar. Lihat http://www. kompasiana.com/kompol52/merenungikenyataandengan-nalar_54f90c05a 33311120a8b4d22, diakses 20 Oktober 2018, pukul 08.53. 


\section{Telaah Kritis Konsep Ide Besar...}

"space time", bukan hanya tiga seperti pada Eucledian geometry. Kedua, pendapat Kant yang menyatakan bahwa jagat raya bukan jagat raya yang sebenarnya, akan tapi merupakan jagat raya yang diciptakan oleh manusia. Ketiga, deterministik Newton kehilangan dasar, maka orang mulai dengan "stochastic" Keempat, partikel-partikel sub atomik terbuka untuk interpretasi spiritual. Kelima, prinsip "uncertainty" sebagaimana yang ditemukan oleh Heinsberg. Keenam, kerusakan ekologi dan atmosfir yang menyeluruh yang disebutnya "planetary ecological crisis" ${ }^{34}$.

Sedangkan menurut Eki Baihaki, secara komprehensif Tarnas mencoba menjelaskan keadaan krisis Sains Barat Modern (SBM), disertai alasan-alasan yang sangat mendasar, dan sulit dibantah. penjelasannya dapat disusun menjadi 5 bagian, sebagai berikut. ${ }^{35}$

Pertama, bahwa 4 teori dasar SBM terbukti keliru (controverted), keempat teori dasar tersebut adalah ruang (space), materi

33 Salah satu indikator yang juga bisa membantu Anda untuk menemukan momentum yang baik untuk menentukan entry point. Lihat http://www.foreximf.com/belajar-forex/dasar/ stochastic-oscillator/

${ }^{34}$ Asumsi yang menjadi pangkal dalil yang dianggap benar tanpa perlu membuktikannya; anggapan dasar; aksioma, lihathttp://kbbi.web.id/ postulat, diakses 20 Oktober 2018, pukul 09.00.

35 Eki Baihaki. (t.t.) Sains Modern: Kontemplasi dan Realita. Lihat http://ekibaihaki .com/article /87422/ sains- modern- kontemplasidan-realita.html, diakses 20 Oktober 2018, pukul 16.12 WIB. (matter), observasi dan kausalitas. Ruang yang awalnya terdiri dari tiga dimensi harus menjadi empat dimensi, maka menjadi ruang waktu. Didapati ruangpun bertopografi, dan di dalam topografi cahaya berjalan dengan lengkung, bukan linier. Koordinat Cartesian-newtonian perlu ditambah waktu. Materi yang katanya solid seperti diungkapkan oleh Demokritos, ternyata di dalamnya terdapat kehampaan seperti pada atom bohr. Observasi kini diragukan kemantapannya, dan mulai disadari bahwa di depan mata setiap orang ada "lensa" yang di bentuk oleh tata nilai yang dianut, pengalaman, aspirasi, harapan, trauma-trauma, dan sebagainya. Maka setiap orang memiliki "cognitive syndrome"nya sendiri. Adapun kausalitas yang kini berlaku ternyata terlalu simplisistik, sebagai akibat dari observasi yang terbatas kemampuannya ("terpola"). ${ }^{36}$

Oleh karenanya menurut Tarnas, akibat kesalahan tersebut, berdampak pada kerusakan yang tidak hanya pada manusia saja, akan tetapi terjadi menyeluruh pada alam maupun pada masyarakat secara umum. Contohnya terjadi pada rusaknya alam seperti rusak lingkungan atau ekologi pada pencemaran di air, udara, tanah, sehingga terjadi dampak buruk pada kehidupan tumbuhan dan hewan, sehingga terjadi kerusakan di muka bumi. Terbukti

36 Eki Baihaki. (t.t.) Sains Modern: Kontemplasi dan Realita. 
SBM tidak memiliki kemampuan untuk memperbaiki diri sendiri, meskipun saintifik SBM menjadi semakin proporsional. ${ }^{37}$.

Kedua, terjadi kesalahan epistemologis. Dasar-dasar epistemologisnya dinyatakan keliru karena yang tampak kepada kita itu bukan jagat raya yang sebenarnya, akan tetapi jagat raya yang sebagaimana dipertanyakan oleh orang (observer). Oleh karenanya beberapa hal dalam paradigm teori sebab-akibat harus direvisi, seperti deterministic Newtonian, kecerdasan electron, prinsip ketidak-pastian (Heisenberg), dan sebagainya. ${ }^{38}$

Ketiga, "Order" newtonian telah runtuh, kini terbuka bagi siapapun untuk melukiskan order dari jagat raya ini. ${ }^{39}$

Keempat, keperilakuan partikelpartikel sub-atomik ternyata terbuka untuk adanya interpretasi spiritual ${ }^{40}$.

Kelima, akibat dari semua hal ini adalah runtuhnya kepercayaan kepada Sains Barat Modern. Para ilmuwan Sains Barat Modern berada dalam kekalutan atau "kalang-kabut", mereka, yaitu orang barat mulai sadar, bahwa mereka telah menyingkirkan agama dalam kehidupan

\begin{tabular}{|c|c|c|}
\hline Eki Baihaki. (t.t.) & Sains & Modern: \\
\hline $\begin{array}{l}\text { Kontemplasi dan Realita. } \\
\qquad 38 \text { Eki Baihaki. (t.t.) }\end{array}$ & Sains & Modern: \\
\hline Kontemplasi dan Realita. & & \\
\hline $\begin{array}{l}{ }^{39} \text { Eki Baihaki. (t.t.) } \\
\text { Kontemplasi dan Realita. }\end{array}$ & Sains & Modern: \\
\hline $\begin{array}{l}\text { Eki Baihaki. (t.t.) } \\
\text { Kontemplasi dan Realita. }\end{array}$ & Sains & Moder \\
\hline
\end{tabular}

mereka dan beralih kepada sains yang penuh dengan "kepastian" itu. Akan tetapi sekarang ternyata bahwa sains itu juga dirundung oleh prinsip ketidakpastian. Sebagai akibat dari tidak benarnya kemampuan observasi manusia. Tarnas mengatakan bahwa SBM perlu direevaluasi sepenuh hati.

Tarnas menutup uraiannya tentang krisis sains barat modern dengan kenyataan bahwa kerusakan-kerusakan semakin menggawat, sehingga Tarnas berkesimpulan atas dasar pertimbangan di atas tersebut, maka pikiran modern kini terpaksa harus me re-evaluasi sains secara sepenuh hati. ${ }^{41}$

\section{TELAAH KRITIS EPISTEMO- LOGI PEMIKIRAN BARAT DALAM UPAYA REKON- STRUKSI PEMIKIRAN PENDI- DIKAN ISLAM}

Telaah kritis terhadap epistemologi pemikiran barat, sesungguhnya tidak hanya disampaikan oleh para pemikir barat sendiri, akan tetapi intelektual muslim tidak absen menelaah persoalan tersebut, terutama pada ranah dan ruang lingkup karakteristik, pandangan, dan sumber ilmu pengetahuan, sebagaimana dijelaskan sebagai berikut:

1. Dari Sudut Pandang Karakteristik Filsafat Barat

41 Eki Baihaki. (t.t.) Sains Modern: Kontemplasi dan Realita. 


\section{Telaah Kritis Konsep Ide Besar...}

Qasim Saguni menyatakan, bahwa pemikiran Filsafat ilmu Barat mendasari pemikirannya dari tradisi rasional dan sekuler Yunani dan Roma. Oleh karenanya tidak berhasil merumuskan kebenaran atas fakta sesungguhnya serta realitas atas dasar prinsip pengetahuan yang berasal dari kebenaran wahyu. $^{42}$ Sebagaimana telah dinyatakan oleh C. A. Qadir, seorang cendikiawan serta ilmuwan Muslim kontemporer dalam salah satu karyanya yang terkenal yaitu Philosophy and Science in the Islamic World. Dimana dalam pandangannya tersebut Ia menyatakan bahwa pengetahuan barat lahir dan berasal dari sumber-sumber pemikiran yang bersifat spekulasi metafisis dari tokoh-tokoh utama pemikirnya yang berpaham evolusi kehidupan dan psikoanalitik tentang kodrat manusia yang bermuara pada usaha desakralisasi pengetahuan. Kemudian arah pandangan desakralisasi benar-benar memotong pengetahuan dari akarnya sampai-sampai pada tingkat telah kehilangan keyakinan pada sesuatu yang sakral. Dampak langsung yang dirasakan dari kecenderungan ini adalah ilmu pengetahuan itu sendiri. Dampak lebih lanjut akibat dari hal di atas adalah

42 Qasim Saguni. Membedah Kesalahan Mendasar dari Filsafat Barat. Lihat http://www.qasimsaguni.com/2009/01/membedahkesalahan-mendasar-dari.html, diakses pada 07 Oktober 2018. pandangan yang mekanistik, tentang sebuah wujud realitas serta munculnya sebuah pandangan dunia yang tidak memberi tempat bagi nilai-nilai kerohanian. Sehingga dapat ditarik kesimpulan bahwa Epistemologi Pemikiran Barat memandang filsafat adalah segala upaya (berfikir filsafati) dalam rangka jalan menemukan kebenaran berdasarkan fikiran atau akal belaka, pemikir filsafat barat bahkan semakin memperjelas pengertiannya dengan mengatakan bahwa kebenaran tersebut dicapai bukan menggunakan wahyu atau ajaran agama, sebab jawaban berdasarkan wahyu atau ajaran agama bukan jawaban berdasarkan fikiran atau akal belaka. Karena itu mereka membedakan antara kebenaran filasafat dengan kebenaran wahyu atau agama. Cara pandang yang seperti inilah yang disebut sekularistik. Pandangan pemikiran sekularistik inilah yang merupakan akar kesalahan konsep epistemologi pemikiran filsafat yang dibangun oleh Barat. ${ }^{43}$

2. Sudut Pandang Sumber Ilmu Filsafat Barat

Qasim juga menyatakan, bahwa permasalahan pokok dalam epistemologi, yaitu tentang sumber Ilmu merupakan permasalahan yang sangat penting dan

\footnotetext{
43 Qasim Saguni. Membedah Kesalahan Mendasar dari Filsafat Barat.
} 
sangat mendasar, karena dari padanyalah berpijak landasan-landasan filosofis ilmu.

Qasim menyatakan bahwa dalam pandangan filsafat sains modern, yang dikenal juga dengan filsafat Barat (baca: filsafat sekularistik), membagi empat sumber ilmu, yaitu: ${ }^{44}$

\section{Pertama, Orang yang Memiliki}

Otoritas, yaitu sebagaimana dinyatakan oleh Qasim, sebagai mereka yang karena otoritasnya, tepat dan relevan dijadikan sebagai sumber pengetahuan tentang suatu permsalahan. Di zaman modern ini, orang yang ditempatkan memiliki otoritas, misalnya, dengan pengakuan melalui gelar, diploma/ijazah. Termasuk juga dalam hal ini, misalnya, hasil publikasi resmi mengenai kesaksian otoritas tersebut, seperti buku-buku atau publikasi resmi pengetahuan lainnya. ${ }^{45}$

Kedua, Indra, Qasim mendefinisikan indra adalah suatu peralatan pada diri manusia sebagai salah satu sumber internal pengetahuan. Untuk memahami posisi indra sebagai sumber pengetahuan biasanya pada pertanyaan kasus masalah misalnya, bagaimana mengetahui bahwa besi memuai bila dipanaskan? Atau air membeku bila didinginkan hingga mencapai derajat kedinginan tertentu?

\footnotetext{
44 Qasim Saguni. Membedah Kesalahan Mendasar dari Filsafat Barat.

45 Qasim Saguni. Membedah Kesalahan Mendasar dari Filsafat Bara..
}

Terhadap pengetahuan semacam itu, filsafat sains modern berpandangan bahwa indra yang menjadi sumbernya. Dalam pandangan pemikiran aliran empirisme yang diterapkan dalam sains modern dinyatakan bahwa pengetahuan pada dasarnya hanyalah pengalamanpengalaman konkrit kita yang terbentuk karena persepsi indra, seperti persepsi penglihatan, pendengaran, perabaan, penciuman dan pencicipan dengan lidah. Namun dalam menempatkan indra sebagai sumber penegetahuan, filsafat ilmu sekuler juga menekankan pentingnya kehatihatian, utamanya terhadap kemungkinan pengaruh prasangka dan emosi yang akan merusak obyektifitas. ${ }^{46}$

Ketiga, Akal, Qasim menyatakan, pada realitanya terdapat pengetahuan tertentu yang bisa dibangun oleh manusia tanpa harus atau dengan tidak bisa mempersepsinya dengan indera terlebih dahulu. Oleh karenanya sesungguhnya manusia dapat mengkonstruksi sendiri pengetahuan, misalnya dari anggapan dua entitas yang masing-masing sama besarnya dengan entitas ketiga adalah entitas sama besar. Konstruksi pengetahuan dengan proses demikian itu tentu saja dengan sendirinya (tanpa persepsi indra), karena ada akal yang memungkinkannya. Argumentasi seperti ini lah yang dibangun

46 Qasim Saguni. Membedah Kesalahan Mendasar dari Filsafat Barat. 


\section{Telaah Kritis Konsep Ide Besar...}

para filsuf ilmu sekuler di dalam usaha melandasi pemikiran mereka mengenai akal sebagai sumber pengetahuan. Atas dasar realita tersebut, maka epistemologi pemikiran sekuler barat dalam memposisikan akal sebagai salah-satu sumber pengetahuan untuk memperoleh pengetahuan ilmiah. Pandangan seperti ini adalah cerminan dari pandangan filsafat rasionalisme, yang dalam pandangannya memiliki pendapat bahwa manusia memiliki potensi mengetahui dengan pasti dengan sendirinya tentang beberapa hal yang relevan. ${ }^{47}$

Keempat, Intuisi, Qasim mengutip George Santayana, bahwa istilah intuisi merupakan kesadaran tentang data-data yang langsung dirasakan. Pada contoh kejadian sewaktu kita mendengar bunyi, maka selain kita mendengar, kita juga sadar tentang pendengaran kita dan sadar tentang diri kita sebagai yang mendengar. Menurut Titus, Smith dan Nolan, intuisi terdapat dalam pengetahuan tentang diri sendiri, kehidupan diri sendiri dan dalam aksioma matematika. Intuisi ada dalam pemahaman kita tentang hubungan antara kata-kata (preposition) yang membentuk bermacam-macam langkah dari argumen. ${ }^{48}$

\footnotetext{
47 Qasim Saguni. Membedah Kesalahan Mendasar dari Filsafat Barat.

48 Qasim Saguni. Membedah Kesalahan Mendasar dari Filsafat Barat.
}

3. Kesalahan Pandangan Filsafat Barat Tentang Sumber Ilmu

Qasim berpendapat, bahwa penting memberikan penjelasan lebih lanjut tentang sumber ilmu menurut epistemology pemikiran Barat, oleh karenanya yang harus terlebih dahulu perlu didefinisikan adalah, pengertian Sumber. Qasim lebih lanjut menjelaskan bahwa secara logika sehat bahwa yang disebut sumber adalah yang tidak pernah tidak memiliki sesuatu.

Ketika seseorang menimba air di sumur, maka timba tidak bisa dikatakan sebagai sumber air, sumber air itu sendiri adalah sumurnya, sedangkan timba yang digunakan hanyalah merupakan alat. Filsafat Barat berkesimpulan bahwa sumber ilmu adalah dari manusia dan alam. Yang menjadi pertanyaan bagi kita adalah apakah manusia dan alam menciptakan dirinya sendiri? Apakah manusia dan alam lahir/tercipta dalam keadaan sudah memiliki ilmu. Logika sehat akan menjawab, manusia dan alam tidak tercipta dengan sendirinya (ada yang menciptakan), kalau begitu manusia dan alam pernah tidak memiliki sesuatu kemudian berusaha untuk memiliki, dalam hal ini ilmu.

Kalau demikian faktanya maka tidaklah benar (baca: kesalahan) yang sangat fatal jika kita mengatakan manusia 
dan alam adalah sumber ilmu. Disinilah letak kesalahan yang paling mendasar dari teori epistemologi pemikiran barat yang memisahkan aktifitas berfikir dengan wahyu. $^{49}$

\section{KESIMPULAN}

Pada bagian akhir ini, penulis menyimpulkan bahwa kelemahan metodologi pemikiran Barat itu terletak pada segi epistemologisnya yang keliru, sains itu berfungsi sebagai explanatory (menjelaskan), sedangkan normatif berfungsi menetapkan mana yang benar dan yang salah. Maka keduanya tidak bisa campur, karena merupakan dunia yang sama sekali berbeda.

Oleh karena itu, penulis menghimbau, hendaknya kita semua, terutama intelektual Muslim, untuk terus mengkritisi metode berpikir dengan menggunakan epistemologi pemikiran barat, sebagai seorang pembelajar Muslim kita tidak harus mengadopsi ilmu-ilmu modern itu apa adanya. Hal tersebut perlu kita lakukan karena bagaimanapun ilmu-ilmu modern itu dibangun di atas kerangka teoritis dan epistemologi pemikiran barat yang tidak seluruhnya selaras dengan pandangan dan esensi ajaran Islam.

Berangkat dari kesadaran tersebut, maka usaha rekonstruksi dan kajian secara

49 Qasim Saguni. Membedah Kesalahan Mendasar dari Filsafat Barat. kritis terhadap ilmu-ilmu tersebut (dalam arti membersihkan ilmu-ilmu modern itu dari bias teori-teori dan pandangan filsafat Barat terkait konsep ketuhanan, alam semesta, manusia, dan kehidupan yang seringkali tidak sejalan dengan ajaran moral Islam) agar selaras dengan orientasi pendidikan Islam, merupakan keharusan. Karena, jika kita mengadopsi ilmu-ilmu tersebut apa adanya dari luar (tanpa upaya rekonstruksi dan penyelarasan dengan ajaran Islam terlebih dulu) dan menerapkannya begitu saja dalam muatan kurikulum pendidikan Islam, maka dapat dipastikan akan berimplikasi pada kerusakan akal dan mental generasi muda yang sebelumnya telah dibangun oleh ilmu-ilmu syariat, khususnya terkait akidah dan penanaman nilai-nilai Islami. Selain itu, mereka (generasi muda) juga tidak menutup kemungkinan akan lebih condong kepada pandangan-pandangan yang bertentangan dengan pandangan Islam dalam memahami alam semesta, kehidupan, dan pola prilaku manusia.

Penulis sepakat pada pendapat yang menyatakan bahwa pengelompokan "ilmu agama" dan "ilmu umum" yang telah tertanam kuat di alam pikiran peserta didik sekarang ini, dikhawatirkan akan membentuk pandangan mereka tentang kehidupan yang kering dari 


\section{Telaah Kritis Konsep Ide Besar...}

dimensi ilahiyah. Karena semua teori keilmuan modern disajikan tanpa sedikitpun menyentuh dimensi al-qudrat al-ilahiyah yang notabene.

Dia-lah yang menciptakan segala sesuatu beserta hukum-hukum alam di dalamnya. Maka tidak mengherankan jika pada gilirannya peserta didik itu melakukan aktivitas-aktivitas kehidupannya tanpa landasan nilai-nilai keagamaan. Dengan kata lain, mereka menjadi acuh terhadap "bisikan suara" Allah yang bersumber dari hati nurani mereka sendiri yang fitri. Padahal, pada saat yang bersamaan mereka juga mempelajari ajaran wahyu tentang bagaimana permulaan terciptanya alam semesta dan kehancurannya. Mereka seolah menemukan dirinya "kebingungan" dimanakah mereka harus "menempatkan" Allah di tengah teori-teori keilmuan modern yang dipelajarinya.

Maka, pemisahan antara ilmu-ilmu syariat (ilmu agama) dan ilmu-ilmu modern (ilmu umum) telah secara nyata menimbulkan kesulitan tersendiri bagi kemajuan umat Islam dalam merespons wacana-wacana modernitas. Pemisahan semacam ini tentunya tidak diajarkan dalam Islam. Oleh karenanya, umat Islam dalam hal ini perlu melakukan upaya rekonstruksi terhadap ilmu-ilmu modern tersebut. Ini penting dilakukan agar terjadi sinergitas antar berbagai bidang ilmu yang ada, demi tercapainya hakikat dan tujuan pendidikan sekaligus agar terwujud kebahagiaan hidup masyarakat yang berlandaskan pada nilai-nilai kemanusiaan dan ketuhanan. Wallahu a'lam bis showab.

\section{DAFTAR PUSTAKA}

Adian, D.G. (2002). Menyoal Objektivisme Ilmu Pengetahuan dari David Hume sampai Thomas Kuhn. Jakarta: Teraju.

Arif, S. (2008). Orientalis dan Diabolisme Pemikiran. Jakarta: Gema Insani.

C. Verhak. (1995). Filsafat Ilmu Pengetahuan. Jakarta: PT. Gramedia Pustaka Utama.

Departemen Pendidikan Nasional. (2008). Kamus Besar Bahasa Indonesia Pusat Bahasa: Edisi Keempat. Jakarta: PT Gramedia Pustaka Utama.

Efendi, R. (2009). Hubungan Antara Sains dan Agama dalam Pemikiran Fritjof Capra. Yogyakarta: UIN Yogya.

Fritjop Capra. (2002). Titik Balik Peradaban. Bentang Budaya.

Husaini, A. (2005). Wajah Peradaban Barat: Dari Hegemoni Kristen ke Dominasi Sekular Liberal. Jakarta: Gema Insani. dan Hidayat, N. (2006). Islam Liberal: Sejarah, Konsepsi, Penyimpangan dan Jawabannya. Jakarta: Gema Insani.

- (2013). Filsafat Ilmu:Perpektif Barat dan Islam. Jakarta: Gema Insani.

(2006).Hegemoni Kristen-Barat dalam Studi Islam di Perguruan Tinggi. Jakarta: Gema Insani. 
(2009).Virus Liberalisme di Perguruan Tinggi Islam, Jakarta: Gema Insani.

Panduan enulisan Tesis dan Disertasi. Bandung: Program Pasca UIN Bandung

Rahman, B.M.et.all. (2004).Jalan Paradoks: Visi Baru Fritjof Capra tentang Kearifan dan Kehidupan Modern. Teraju Mizan.

Santoso, L. (2006). Seri Pemikiran Tokoh: Epistemologi Kiri. Jogjakarta: ArRuzz Media.

Soewardi, H. (2000). Mempersiapkan Kelahiran Sains Tauhidulloh. Bandung.

Soewardi, H. (1999). Roda Berputar Dunia Bergulir,Cognisi Baru, Timbul Tenggelamnnya Sivilisasi. Bandung: Bakti Mandiri.

Sugiarto, I.B. (2008). Postmodernisme: Tantangan Bagi Filsafat. Yogyakarta: Kanisius.

Suriasumantri, J.S. (1978). Ilmu dalam Perspektif. Jakarta: Gramedia.

Tasir, Moch. (2014).Paul Karl Feyerabend; Anything Goes Methode. Lihat http:// philosopher scommunity. blogspot.co. id/ 2014/03/ paul-karl-feyera bendanything- goes. Html,diakses 20 Oktober 2018, pukul 14.06.

http://ekibaihaki. com/article/87422/sainmodern- kontemplasi-dan-realita. html.

http:// kuliahfilsafat. com/ tag/ paulfeyerabend/.

http://philosopherscommunity.blogspot.co. id/2014/03/paul-karl-feyerabendanything-goes.html.

http://www.fritjofcapra.net/.

http://www.kompasiana.com/kompol52/me renungi-kenyataan-dengan-nalar 54f90c05a 33311120a8b4d22.

http://www.qasimsaguni.com/2009/01/me mbedah-kesalahan- mendasar-dari. html.

http://www.salehdaulay.com/index.php/co mponent/k2/item/110-menelusuri-jejakjejak-mistis me-dalam-sains-modern. https://id.wikipedia.org/wiki/Anarkisme_ep istemologis. 
